\title{
Calorie-Fluid Relationship According to Avicenna
}

\author{
Hussain Sikandar* \\ Professor of Physiology, VRK Women's medical college, India
}

*Corresponding author: Hussain Sikandar, Professor of Physiology, VRK Women's medical college, India.

Received Date: July 07, 2019

Published Date: July 31, 2019

\section{Introduction}

Whether life originated in water on the surface of earth or on some other planet, whether it originated at one place or from several loci simultaneously? Irrespective of the solution to above problems, the basic principle remains true that life is not possible without fluid. Body fluids are the cradle for life, and these form the internal environment of our body. Metabolic changes are continuously occurring in living body cells thereby changing their water content and energy status every moment. water in the cells is always mixed with other protoplasmic constituents and therefore is referred as fluid by Avicenna. One thousand years back great Ismaili physician Avicenna has described body fluids in a very scholarly and unique manner. Ahead of modern classification as intracellular and extracellular compartments he first classifies body fluids as primary and secondary, and then breaks these categories into various sub compartments. Discussing the physiological role of these compartments and sub compartments, he relates these to metabolic status of the body. For example, during catabolism fluid is used and heat is produced and vice versa in anabolism. Thus, thousand years back he has postulated a very ingenious concept of fluid dynamics

which can be termed as "calorie- fluid relationship". As a humble student of physiology, I want to present before you some glimpses of this concept from his famous book "CANNON OF MEDICINE" and hope that it will provide a new scientific and physiological approach to the concept of fluid dynamics.

\section{Classification of Fluid Compartments}

Avicenna classified body fluids in a very scientific manner into primary and secondary fluids. Primary fluids are those which can absorb nutrients directly from the food and thus are in contact with the lumen of the gut, whereas secondary fluids receive thesenutrients indirectly through the primary fluids. Primary fluids (علوا تابوطر) are the four classical humours present in the

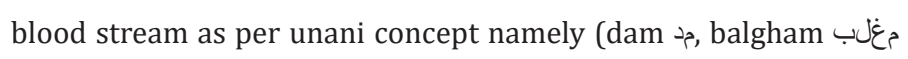
safra (ادوس and sauda). Secondary fluids (قئناث تابوطر) include interstitial fluid (فنواجت تبوطر) أرور) and intra cellular fluids (ع) (اضعالا تبوطر). A very interesting fact is that Avicenna, on par with modern physiology, described various subdivisions of intracellular fluid. He describes three important divisions of ICF namely Depot fluid, ثنىل تبط تبوق تبوطر Metabolic fluid

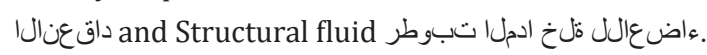

(above terms are self-explanatory). It is a credit for Avicenna that just logically without the aid of microscope and biochemical tests he was able to peep into the cell and describe these minute details.

\section{Function of Body Fluids}

The main function of the body fluids, according to Avicenna, is leadingfood towards tissues, through primary then secondary fluids, thus allowing tissues to replace damaged and used constituents of protoplasm. The metabolic fate of dietary components releases energy and heat (calorific value) which will always be related to the quality and quantity of the food absorbed. Thus, the caloric content of the food is an important factor in the phenomenon of growth. The specific relationship between fluid content and heat content of the living cells is emphasized by Avicenna in his book "Risalatul Adviatul Qalbia" (مىبلقلا ثىودالا ةلاسر tract on cardiac drugs) where he not only discusses and defines" temperament" (ج) (but also describes the conditions favourable for life. He defines temperament as the "intermediate position between the two opposite properties of water content (dryness and wetness) and heat content (hot and cold). He states that this intermediate position is not necessarily the middle or average position but may lie on any side of the range. It is this intermediate position which is most suitable for origin and maintenance of life. Avicenna supports his above hypothesis by stating that "elements can never obtain life whereas only compounds can get life". Combination of different 
elements in a compound neutralizes their opposite properties and may create a temperament suitable for synthesis and maintenance of life.

\section{Fertilization and Calorie - Fluid Relationship}

According to Avicenna both male semen(sperm)and female semen (ovum) contain in common a fluid part, but the difference lies in the energy content. Sperm is having more energy content (naariر) in its middle piece whereas ovum is having more solid earthly constituents. Sperm is the cause of triggering activity in the ovum, which contains the basic material for embryogenesis. During fertilization solid constituents of the ova are energized by sperm in their common fluid medium. The resulting zygote from that time onwards till its death is under two types of influences (aafat تاف). First is the gradual degradation or lysis (tahleel لكىلحت) of the fluid bound to the tissues (hararate ghareezi نىزىرغ تر ارح). Second is the putrefaction (taaffun نففع) of this fluid leading to its disorganisation. Thus, Avicenna for the first time directs our attention to the fact that phenomenon of ageing stars from the time of fertilization itself. Heat produce by the normal breakdown of the tissues (hararate ghareezi (ىزىرغ ترارح) causes lysis, whereas heat liberated by the food (hararate ghareebi كبىردغترارح) causes putrefaction, both changes results in drying of the fluids. Consequently, there is a decrease in the capacity of the nutrients to get converted into tissue followed by gradual loss of capacity to support life finally leading to death.

\section{Age and Calorie - Fluid Relation Ship:}

The basic cause for the difference in growth rate at various ages, according to Avicenna lies in the difference of fluid content and basal metabolic rate (hararat gharizia (نىزىرغ تر ارح). He says that there is arelationship between the heat produced in the body (hararateghareezi (ىزىرغ ترارح) and the amount of fluids present in the body (rutubate badani عندب تابوطر ترعر). This calorie-fluid relationship, which is present since birth to death, is the basis for growth and senescence. Though both fluid content and heat production decrease with age but not in the same proportion. During period of growth (sene hadasat تث نادح نس) fluid is more to support growth and also to protect from metabolic heat. During period of arrest of growth (sene waqoof فوقو نس) fluid is decreased moderately so that it can only protect the tissues from heat but cannot support growth.

During period of senescence (sene inhitat طاطحنا نس) fluid is decreased to such an extent that it cannot even protect the ترارح (sزى) Avicenna says that structural fluid is to the body what oil is to a burning lamp. Heat and fluids have an effect on each other. A decrease in the fluid causes a parallel decrease in heat production. On the other hand, metabolic heat tends to dry structural fluids from the beginning of our life. This rate of drying is gradually increasing with the advancement in age and finally a stage comes when fluids are so much reduced that there will be no heat production. In other words, oil is decreased to such an extent that it cannot burn the lamp and that is the end of life.

\section{Acknowledgements}

None.

\section{Conflict of Interest}

No conflict of interest. 